\title{
THE VALUE OF CSF ANALYSIS FOR THE DIFFERENTIAL DIAGNOSIS OF HTLV-I ASSOCIATED MYELOPATHY AND MULTIPLE SCLEROSIS
}

\author{
MARZIA PUCCIONI-SOHLER ******, BERND KITZE*, KLAUS FELGENHAUER*, \\ IRIS T. GRAEF*, PETER LANGE*, SERGIO NOVIS** , HANSOTTO REIBER*, BEATRIZ VAZ**
}

SUMMARY - Cerebrospinal fluid (CSF) and serum of 17 patients with HAM/TSP (HTLV-I associated myelopathy/ tropical spastic paraparesis), six with multiple sclerosis and six with idiopathic epilepsy (non inflammatory control) from Brazil were analysed for the presence of intrathecal synthesis of virus-specific antibodies against measles, rubella, varicella zoster virus and herpes simplex virus by enzyme-linked immunosorbent assay (ELISA). All HAM/TSP and multiple sclerosis cases had an intrathecal immune response (oligoclonal IgG). In HAM/TSP, only $1 / 17$ case showed a polyspecific intrathecal immune response against measles and rubella virus. In multiple sclerosis, specific antibodies against measles and rubella (MRZ response) were observed in all patients but not in the control with idiopathic epilepsy. The diagnostic and theoretical relevance of mono- and polyspecific immune responses is discussed for these chronic neurological diseases.

KEY WORDS: HTLV-I, HAM/TSP, cerebrospinal fluid, antibody index

Valor da análise do LCR para o diagnóstico diferencial de mielopatia associada ao HTLV-I e esclerose múltipla

RESUMO - Amostras de líquido cefalorraquidiano (LCR) e soro de 17 pacientes brasileiros com HAM/TSP, seis com esclerose multipla e seis com epilepsia idiopática (controle não-inflamatório) foram analisadas para a presença de anticorpos para os virus do sarampo, rubéola, varicela zoster e herpes simples pelo método de ELISA. Todos os casos de HAM/TSP e esclerose múltipla tinharn resposta imune intratecal (IgG oligoclonal). Somente $1 / 17$ casos de HAMTSP apresentavam resposta imune poliespecifica intratecal para sarampo e rubéola. Anticorpos específicos para sarampo e rubéola (resposta MRZ) foram observados em todos os pacientes com esclerose multipla, mas não nos controles com epilepsia idiopática. A relevância das respostas poliespecifica e monoespecifica é discutida para essas doenças neurológicas crônicas.

PALAVRAS-CHAVE: HTLV-I, HAM/TSP, líquido cefalorraquidiano, índice de anticorpos.

The sensitive detection of intrathecally synthesized antibodies increased the relevance of $\mathrm{CSF}$ analysis for diagnosis of neurological diseases ${ }^{17}$. The sucessful concepts for discrimination of blood derived and brain derived CSF fractions ${ }^{16}$ of immunoglobulin could be extended to the detection of brain defined specific antibodies exceeding the theoretical upper concentration of blood derived antibody species in CSF. An immune response against virus antigens within the central nervous system (CNS) has been demonstrated in different neurological disease ${ }^{14,6,7}$. This reaction may be

*Neurochemistry Labor - Klinik und Poliklinik für Neurologie der Georg-August-Universität Göttingen, Germany; **Serviço de Neurologia, Universidade Federal do Rio de Janeiro (HUCFF/UFRJ), Brazil; ***Fellowship from DAAD and CNPq/CAPES. Aceite: 18-agosto-1995. 
monospecific against the causal agent in acute infections of the CNS such as in herpes simplex, zoster and HIV-1 encephalitis, neurosyphilis and neuroborreliosis ${ }^{1,2,13}$. On the other hand, a polyspecific reaction against measles, rubella, varicella zoster virus (VZV) and herpes simplex virus (HSV) has been detected in patients with chronic inflammatory neurological disorders such as: multiple sclerosis (MS) ${ }^{2,3}$, chronic neuroborreliosis ${ }^{18}, \mathrm{CNS}$ involvement of systemic autoimmune diseases ${ }^{6}$ and in the later stages of HIV.1 encephaliti ${ }^{13}$. It seems not to be related with the persistence of these viruses in the CNS and is explained as an unspecific stimulation of B cells in the CNS ${ }^{5}$. It is used as an additional diagnostic test especially in MS and other autoimmune processes of the CNS ${ }^{2}$. A specific antibody index has been used to quantitate the local synthesis of antibodies against viruses and bacterias ${ }^{17}$, a very sensitive and specific diagnostic marker in inflammatory diseases ${ }^{2}$.

The purpose of this study was to analyse the intrathecal synthesis of antibodies against measles, rubella, VZV (MRZ response) and HSV in Brazilian patients with chronic inflammatory diseases of the CNS as HAM/TSP and MS as well as idiopathic epilepsy as non-inflammatory control. The comparison with data from European patients is discussed.

\section{PATIENTS AND METHODS}

Lumbar CSF and blood samples were collected from 17 patients with HAM/TSP, six with MS and six with idiopathic epilepsy of the Neurologic Clinic of the Clementino Fraga Filho Hospital, Federal University of Rio de Janeiro, Brazil. Nine patients with HAM/TSP were Caucasian, four of African descendent and four of mixed ethnic origin (African and Caucasian). Five patients with MS as well five with epilepsy were Caucasian, one with MS was African descendent and one with epilepsy was of mixed ethnic origin. Epidemiological and clinical data together with detailed data of CSF diagnosis have been reported elsewhere ${ }^{14}$.

Assays

Antibodies to HTLV-I were detected in the serum of all HAM/TSP patients with a commercial enzyme immunoassay (Du Pont) and the positive samples were confirmed by radioimmunoprecipitation and polymerase chain reaction.

Albumin and IgG were measured in CSF and serum by nephelometry. CSF/serum quotients were calculated $^{17}$. The presence of oligoclonal bands in CSF and serum was analysed by isoelectric focussing.

Levels of antibodies against measles, rubella, VZV and HSV in paired samples of CSF and serum were analysed by ELISA and evaluated according to Reiber and Lange ${ }^{13}$.

Standards for reference curve were obtained from pooled sera from different patients. Standards were diluted in steps 1:2 to obtain an absorbance in the range of 0.05-2.0 O.D. in the assay. The highest standard without 2.0 O.D. was defined as to have an arbitrary concentration. The dilutions of samples were prepared as follows:

- HSV : $1: 30$ and $1: 160$ for CSF; $1: 6000$ and $1: 30000$ for serum.

- Measles, rubella and VZV: 1:16 and 1:75 for CSF; 1:3000 and 1:16000 for serum.

First, the commercial plates coated with antigen and negative control (not infected cells) were washed once (SLT, Labinstruments EAWII). Seven standards, one positive control, two diluted serum and CSF samples of each patient were added (in duplicate for wells with antigen and with control antigen) to the wells. After overnight incubation at $4^{\circ} \mathrm{C}$, the plates were washed twice and $160 \mu \mathrm{l}$ peroxidase conjugated antibody (goat, anti-human/Sigma Co), diluted 1:1000, was added. After 90 minutes incubation at room temperature, the plate was washed twice and incubated for 20 minutes with $O$-phenylendiamin at room temperature and stopped with $100 \mu \mathrm{H} 2 \mathrm{SO} 4$.

The antibody index $(\mathrm{AI}=\mathrm{Q} \mathrm{AB} / \mathrm{Q} \mathrm{IgG})$ was calculated with the specific CSF/serum antibody quotient $(\mathrm{Q} A B)$ and the actual IgG quotient (Q IgG). In cases of intrathecal IgG synthesis (IgG loc> 0), QIgGlim was used instead of $Q$ IgG act ${ }^{17}$. The Qlim represents the upper value of the IgG fraction from blood for the patient's actual blood-CSF barrier function as measured by $\mathrm{QAlb}{ }^{17}$. In normal conditions the CSF/serum antibody quotient is identical to the total IgG quotient because both have the same permeability across the blood-CSF barrier (AI $=0.7-1.3$ ). Values above 1.5 indicate an intrathecal synthesis of antibodies ${ }^{17}$. 
Table I. Ansibody index (AI) values of 6 MS cases and 6 idiopathic epilepsy from Brazil.

\begin{tabular}{|c|c|c|c|c|}
\hline Patient & Measles & Rubella & VZV & HSV \\
\hline \multicolumn{5}{|c|}{ A. Multiple sclerosis } \\
\hline 1 & 9.2 & 25.5 & 2.2 & 7.6 \\
\hline 2 & 2.4 & 3.7 & 1.1 & 1.0 \\
\hline 3 & 5.4 & 4.5 & 1.4 & 2.0 \\
\hline 4 & 1.9 & 1.6 & 6.1 & 9.4 \\
\hline 5 & 5.8 & 2.0 & 3.3 & 1.5 \\
\hline 6 & 3.7 & 21.3 & 1.1 & 2.8 \\
\hline \multicolumn{5}{|c|}{ B. Idiopathic epilepsy } \\
\hline 1 & 0.8 & 1.3 & 0.9 & 1.2 \\
\hline 2 & 0.7 & 1.0 & 0.9 & 0.9 \\
\hline 3 & 0.9 & nd & nd & 1.1 \\
\hline 4 & 1.0 & 0.8 & 1.5 & 1.0 \\
\hline 5 & 0.8 & 0.8 & 1.5 & 1.0 \\
\hline 6 & 0.8 & nd & 1.0 & 1.1 \\
\hline
\end{tabular}

nd, not detectable.

Table 2. Frequence of specific intrathecal HTLV-l antibodies and of MRZ response.

\begin{tabular}{lccc}
\hline & $\begin{array}{c}\text { HTLV-I } \\
\text { AI }>1.5\end{array}$ & $\begin{array}{c}\text { MRZ response } \\
\text { positive }\end{array}$ & $\begin{array}{r}\text { Oligoclonal } \\
\text { CSF band }\end{array}$ \\
\hline \hline $\begin{array}{l}\text { HAM/TSP } \\
(\mathrm{n}=17)\end{array}$ & 14 & 1 & 17 \\
$\begin{array}{l}\text { Multiple sclerosis } \\
(\mathrm{n}=6)\end{array}$ & 0 & 6 & 6 \\
$\begin{array}{l}\text { Epilepsy } \\
(\mathrm{n}=6)\end{array}$ & 0 & 0 & 0 \\
\hline
\end{tabular}

Table 3. Frequency of intrathecal antibody sysnthesis in different diseases.

\begin{tabular}{|c|c|c|c|c|c|c|}
\hline & $\begin{array}{l}\text { Oligoclonal } \\
\text { IgG bands }\end{array}$ & $\mathbf{M}$ & $\mathrm{R}$ & VZV & HSV & MRZ \\
\hline MS (Ref.2) & $98 \%$ & $79 \%$ & $70 \%$ & $62 \%$ & $30 \%$ & $94 \%$ \\
\hline Neuro-SLE (Ref.6) & $20 \%$ & $30 \%$ & $30 \%$ & $44 \%$ & $11 \%$ & $30 \%$ \\
\hline HAM/TSP & $100 \%$ & $6 \%$ & $6 \%$ & $6 \%$ & 0 & $6 \%$ \\
\hline
\end{tabular}




\section{RESULTS}

The MS data of patients from Brazil confirm the data reported for patients in Germany ${ }^{2}$. All MS patients had increased AI-values for at least 2 species. The control patients showed normal values in the range 0.7 to 1.5 . Table 1 summarises the AI data of the MS and control patients. The HAM/TSP and MS cases had oligoclonal bands in CSF i.e. an intrathecal humoral immune response (Table 2). In HAM/TSP, one of 17 patients had measles ( $\mathrm{AI}=1.8$ ) and rubella $(\mathrm{AI}=2.7)$ antibodies (MRZ) and another a singular VZV response $(\mathrm{AI}=3.4)$. One of these was African descendent and the other of mixed ethnic origin. These patients had no symptoms of measles, rubella or zoster infections. In three HAM/TSP patients, no intrathecal HTLV-I-antibody synthesis was detectable (Table 2) despite elevated HTLV-I antibody titres in blood ${ }^{14}$.

No HTLV-I antibody have been detected in our MS patients. Table 3 shows the frequency of intrathecal synthesis of antibodies in different diseases. For discussion we refer the MS and HAM/ TSP cases to the data of patients with systemic lupus erythematosus with CNS involvement (neuroLE) with a moderate frequency of humoral immune response in CNS.

The group of patients with idiopathic epilepsy had normal CSF data and no intrathecal synthesis of antibodies. In these cases the M, R, Z, H antibodies in CSF are completely blood-derived.

\section{DISCUSSION}

An intrathecal production of HTLV-I antibodies has been observed in most (14/17) HAM/ TSP patients ${ }^{1,4}$. In $3 / 17$ cases the intrathecal synthesis remained below the statistically defined limit (30\% intrathecal synthesis), with AI values between 0.7 and 1.3. In analogy to HIV-1 infection, the HTLV-I myelopathy may therefore be considered as a chronic myelitis ${ }^{13}$. HTLV-I infection of the CNS has been related to the etiology of HAM/TSP. The HTLV-I causes a persistent infection in CNS and the virus has been demonstrated in peripheral blood lymphocytes and CSF cells ${ }^{9,11}$. The intrathecal synthesis of HTLV-I antibodics may be an indicator of the presence of this virus in CNS and differentiates HAM/TSP from other chronic myelopathies such as MS. The high frequency of intrathecal HTLV-I-antibodies signifies a specific and sensitive diagnostic parameter 1,4,12.

In many other viral infections, specific antibodies in CSF have been observed as a sensitive indicator, e.g. in subacute sclerosing panencephalitis (measles) and rubella panencephalitis ${ }^{2}$. This index has a great diagnostic value in cases of facial paresis (VZV or borrelia as cause) ${ }^{2}$. Intrathecal VZV antibodies become detectable around the 5 th day in cases of benign aseptic meningitis and by the 3th day in zoster ganglionitis ${ }^{2}$. In HSV and VZV encephalitis the local immune reaction can be demonstrated during the second week of the disease ${ }^{2}$.

Besides the specific monoviral immune response, we observe a polyspecific antibody synthesis in several chronic diseases, preferentially of the autoimmune type ${ }^{3.16}$. This polyspecific intrathecal reaction seems not to be related with the persistence of the viruses in CNS ${ }^{5}$. In a study from Germany, it was observed that $94 \%$ of the MS patients had an intrathecal immune response against measles, rubella and/or zoster virus ${ }^{2}$. However measles, mumps and rubella viral genomic sequences from MS brain tissues have not been detected .

Some studies have demonstrated that geographic factors may influence the anti-viral response in MS. No antibody titres against measles virus have been detected in MS patients from Japan?, whereas it represents the dominant reaction in MS patients from Europe ${ }^{3}$. Here, we found that all six Brazilian MS patients had an intrathecal synthesis of specific antibodies against measles and rubella and three of them against VZV.

A polyviral immune response in the CNS is not specific for MS, it may be also observed in other autoimmune processes of the CNS as systemic lupus erythemathosus, Sjögren syndrome and Wegener's granulomatosis' ${ }^{6}$. In several other chronic inflammatory diseases as neurosyphilis, MRZ responses so far have not been found $d^{3,18}$. 
Only in two of $17 \mathrm{HAM}$ /TSP cases, a weak antibody response was found against one or two of those virus analysed. The possibility cannot be excluded that the one patient's isolated intrathecal VZV response reflects a specific anamnestic reaction, since VZV infections are rather frequent in the normal population.

High antibody titers in blood to Epstein-Barr virus (EBV) was already demonstrated in HAM/ TSP patients but Itoyama et $\mathrm{al}^{8}$ failed to detect immune response against $\mathrm{HSV}, \mathrm{VZV}$, Japanese encephalitis virus, measles or rubella virus in such cases.

The relevance of the antiviral immune reaction observed in MS and in other chronic inflammatory diseases of the CNS remains unknown. It has been suggested that the continuous virus antibody production could be the result of a polyclonal activation of memory B lymphocytes ${ }^{10}$. As those viral antigens have not been shown in CNS, it has been proposed that the memory cells could be attracted to the CNS and then activated due to an immunologic defect ${ }^{2,19}$

Oligoclonal bands of local origin are present in all inflammatory diseases with a humoral type immune response, including HAM/TSP, MS, neuro-SLE and several infectious brain diseases ${ }^{2,3}$. Presumptive autoimmune diseases of the brain including MS and neuro-SLE are characterized by a polyviral response preferentially against the neuroviroses measles, rubella and zoster: "MRZ- reaction" (so called bystander or nonsense response). HAM/TSP does not exhibit a MRZ reaction, but as most other chronic infectious diseases, a local anti-HTLV-I response with ASI values above 1.5 (ASI = antibody specificity index). There is no correlation between CSF immunoglobulin or antibody levels and the clinical symptoms ${ }^{14,15}$. The CSF levels depend much more on the localization of the inflammatory lesions than on their inflammatory, destructive activities ${ }^{23}$.

Aknowledgements - We would like to thank Dr. C. Poser for the review of this manuscript.

\section{REFERENCES}

1. Ceroni M, Piccardo P, Rodgers-Johnson P, Mora C, Asher DM, Gajdusek DC, Gibbs CJ. Intrathecal synthesis of IgG antibodies to HTLV-I supports an etiological role for HTLV-I in tropical spastic paraparesis. Ann Neurol 1980, 23(Suppl):188-191.

2. Felgenhauer $\mathrm{K}$, Reiber $\mathrm{H}$. The diagnostic significance of antibody specificity indices in multiple sclerosis and herpes virus induced diseases of the nervous system. Clin Investig 1992, 70:28-37.

3. Felgenhauer K, Schädlich H -J, Nekic M, Ackermann R. Cerebrospinal fluid virus antibodies: a diagnostic indicator for multiple sclerosis? J Neurol Sci 1985, 71:291-299.

4. Gessain A, Caudie C, Gout O, Vernant J-C, Maurs L, Giordano C, Malone G, Tournier-Lasserve E, Essex $M$, de-The $G$. Intrathecal synthesis of antibodies to human $T$ lymphotropic virus type $I$ and the presence of IgG oligoclonal bands in the cerebrospinal fluid of patients with endemic tropical spastic paraparesis. $J$ Infect Dis 1988, 167:1226-1234.

5. Godec MS, Asher DM, Murray RS, Shin ML, Greenham LW, Gibbs CJ, Gajdusek DC. Absence of measles, mumps, and rubella viral genomic sequences from multiple sclerosis brain tissue by polymerase chain reaction. Ann Neurol 1992, 32:401-404.

6. Graef IT, Henze T, Reiber H. Polyspezifische Immunreaktion im ZNS bei Autoimmunerkrankungen mit ZNS-Beteiligung. Zarztl. Fortbild 1994, 88:113-117.

7. Horikawa Y, Tsubaki T, Nakajima M. Rubella antibody in multiple sclerosis. Lancet 1973, 1:996-997.

8. Itoyama Y, Minato S-I, Kira J-I, Goto I, Okochi K, Yamamoto N. Immunological aspects of HTLV-I-associated myelopathy (HAM). In Roman G, Vernant J-C, Osame M (eds). HTLV-I and the nervous system. New York Alan R. Liss, p 287-295, 1992.

9. Jacobson S, Gupta A, Mattson D, Mingioli E, McFarlin DE. Immunological studies in tropical spastic paraparesis. Ann Neurol 1989, 27:149-166.

10. Kinnunen E, Valle M, Piirainen L, Kleemola M, Kantanen $M-L$, Juntunen J, Klockars M, Koskenvuo $M$. Viral antibodies in multiple sclerosis: a nationwide co-twin study. Arch Neurol 1990, 47:743-746.

11. Kira J-I, Itoyama Y, Koyanagi Y, Tateishi J, Kishikawa M, Akizuki S-I, Kobayashi I, Toki N, Sueishi K, Sato H, Sakaki Y, Yamamoto N, Goto I. Presence of HTLV-I proviral DNA in central nervous system of patients with HTLV-I-associated myelopathy. Ann Neurol 1992, 31:39-45. 
12. Kitze B, Turner RW, Burchhardt M, Poser S, Hunsmann G, Weber T. Differential diagnosis of HTLV-Iassociated myelopathy and multiple sclerosis in Iranian patients. Clin Investig 1992, 70:1013-1018.

13. Lüer W, Poser S, Weber T, Jürgens S, Eichenlaub D, Pohle HD, Felgenhauer K. Chronic HIV encepalitis: I. Cerebrospinal fluid diagnosis. Klin Wochenschr 1988, 66:21-25.

14. Puccioni-Sohler M, Kitze B, Felgenhauer K. HTLV-I associated myelopathy (HAM/TSP) in patients from Brazil and Iran; neurological manifestations and CSF findings. Arq Neuropsiquiatr 1995, 52: 213-217.

15. Puccioni-Sohler M, Rieckmann P, Kitze B, Lange P, Abrecht M, Felgenhauer K. A soluble form of tumor necrosis factor receptor in cerebrospinal fluid and serum of HTLV-I-associated myelopathy and other neurological diseases. J Neurol 1995, 242: 239- 242.

16. Reiber H. Flow rate of cerebrospinal fluid (CSF): a concept common to normal blood-CSF barrier function and to dysfunction in neurological disease. J Neurol Sci 1994, 122: 189-203.

17. Reiber $\mathrm{H}$, Lange $P$. Quantification of virus-specific antibodies in cerebrospinal fluid and serum: sensitive and specific detection of antibody synthesis in brain. Clin Chem 1991, 37:1163-1160.

18. Schädlich H-J, Mohrmann G, Nekic M, Felgenhauer $K$. Intrathecal synthesis of virus antibodies: a diagnostic test for multiple sclerosis. Eur Neurol 1990, 30:302-304.

19. Varela FJ, Coutinho A. Second generation immune networks. Immunol Today 1991, 12:166-169. 